\section{Freedom to conduct research}

SIR-The near coincidence of the publication of letters from Donald Kennedy (president of Stanford University; Nature 341, 180; 1989) and Norman R. Saunders of Southampton (Nature 341, 99; 1989) prompts us to write. The former was in regard to Alex Comfort's claim that academics generally show cowardice in the face of external attack, while the latter dealt in part with the inappropriate comments of Clive Hollands (Nature 339, 248 ; 1989) about a paper from the INSERM group on development of the primate visual system (Nature 337, 265$267 ; 1989)$. We were beginning to think that Colin Blakemore (Nature 339, 414; 1989) was the only scientist in Britain with the courage to speak out on an issue of fundamental importance to all scientists: namely, the freedom to conduct research without unwarranted obstruction or meddling. The reticence of scientists on both sides of the Atlantic to speak out in response to attacks by antivivisectionists such as Hollands tends to confirm Comfort's assertion.

We, too, question the propriety of a member of Britain's Animal Procedures Committee (APC) passing moral judgement on research he apparently knew little about in such a public forum as the Correspondence pages of Nature. At the very least, Hollands' credibility in terms of being seen as fair-minded in carrying out his duties on the APC has been compromised. Further, Hollands' decision to identify himself in the letter as a member of the Committee for the Reform of Animal Experimentation is troubling, and raises the question: is it appropriate for members of animal research 'reform' groups to serve on committees that regulate animal research? Do we really

\section{ECU too}

SiR-Fred Hoyle (Nature 341, 380; 1989) finds that the term ECU (European Currency Unit) induces pictures of infinities of little grey men in a very large grey building in his mind. If he respells it, he will find the image quite changed.

The word "ecu" sounds to me like something small, hard and shiny (for example money). It is pronounceable in every European language (with the obvious exception of Greek, which does not have a "c"), and it is short enough to require no further abbreviation.

Provided it does not mean anything foul or ridiculous in any European language, why look further?

ANDREW JENKINS AS Telelab, Strømdaljordet 4, Postboks 1868, Gulset, 3701 Skien, Norway want foxes minding our research henhouses?

We do not question the necessity of regulating animal research, nor do we question the desirability of having as members of regulatory committees people who are truly concerned about animal welfare. Indeed, everyone who works with animals in any way should be concerned with their welfare, and happily the vast majority of scientists are so concerned. Our apprehension lies with empowering 'false moderates' who cloak their true antivivisection/antiscience agenda with euphemisms. Is this paranoia? We think not. As you point out in your leading article (Nature 339, 491; 1989), conditions for and treatment of animals in research laboratories are improving, in part because of the clamour made by animal activists, many of whom claim to be concerned only with improving welfare. But the hypocrisy of this claim is well illustrated by recent experiences of our university and nearby Stanford. Both universities have been making great efforts at considerable cost to replace antiquated research facilities with state-ofthe-art laboratories that will greatly improve the animals' environment. Nevertheless, these changes have been met by the animal 'welfare' advocates not with appreciation but with lawsuits and ever-increasing pressure to halt construction. It seems that every new regulation, stipulation or increased cost of doing animal research is viewed by the antivivisectionists as a victory, and causes them to redouble their efforts to halt such research by whatever means they choose to use. For the 'moderates', it means more lobbying for more expensive and restrictive regulations; for the extremists it means vandalism, theft, arson, bombs and death threats (so far). The silence of the vast majority of scientists on this issue may ensure successs for the antivivisectionists, and once again, in the words of Dr Mary Putnam Jacobi when she testified in 1900 against a bill that would have curtailed animal research in the District of Columbia, we shall see "the domination of knowledge by ignorance".

CHARLES S. NICOLL SHARON M. RUSSELL

Department of Integrative Biology,

University of California, Berkeley,

Berkeley, California 94720, USA

SIR-The US Department of Agriculture (USDA)'s "dramatic about-turn" allowing research institutions "themselves to decide how to meet the required standards" of animal care (Nature 341, 6; 1989) will add to the already substantial abuse of animals in laboratories. As it is, USDA officials rarely inspect laboratories more than once a year, if that. Violations of the Animal Welfare Act often go undetected, and if they are reported, there may be no follow-up to ensure compliance with the law. Animal protection organizations have exposed blatant violations and abuse that would otherwise still occur.

USDA's authority over laboratories needs to be strengthened, as does the Animal Welfare Act. Allowing researchers to police themselves will result in conditions that benefit the research budget, not the animals.

K. S. GUillermo

People for the Ethical

Treatment of Animals,

PO Box 42516 .

Washington, DC 20015, USA

\section{Nature conservancy}

SIR-As the British government's proposals to split up the Nature Conservancy Council (NCC) will undoubtedly generate much public debate during the next 18 months or so, I should like to correct some inaccuracies in Ben Webb's recent article (Nature 341, 94; 1989).

First, NCC has no statutory responsibility for archaeological sites. Its remit covers the conservation of flora and fauna as well as features of geological or physiographical importance.

Second, before 1973, the then Nature Conservancy did carry out research, but following the formation of NCC this function was handed over, in part only, to the Institute of Terrestrial Ecology (ITE). But NCC's Chief Scientist's Directorate (CSD) coordinates or conducts a wide range of research and survey work necessary for NCC to exercise its diverse functions throughout Great Britain. To say that those opposing the government's proposed reorganization are unlikely to "seek to put the clock back to when NCC had a research capability of its own" is misleading, NCC utilizes such a research capability today. Indeed, the CSD provides the science base and overview upon which many areas of the NCC's work are justified and built.

Third, while Webb focuses on the need for plans to encourage farmers to take into account environmental considerations, no mention is made of other land uses and development pressures. The forthcoming debate will by no means linger on the farming community; many of the problems of conservation in Great Britain today are caused by other socio-economic factors related to industrial and residential development, transport and infrastructure provisioning, forestry and recreational pressures on seminatural and other habitats of importance for wildlife.

PETER J. EWINS

Nature Conservancy Council,

Archway House, 7 Eastcheap,

Letchworth, Herts SG6 3DG, UK 